\title{
Experimental analysis of longitudinal shear of composite slabs
}

\section{Análise experimental do cisalhamento longitudinal de lajes mistas}

\author{
G. F. J. BRITTO \\ guilhermino.f@hotmail.com \\ https://orcid.org/0000-0003-0705-1997 \\ V. S. SILVA a \\ vanessass@ufba.br \\ https://orcid.org/0000-0003-2478-2353 \\ J. P. GONÇALVES a \\ jardelpg@gmail.com \\ https://orcid.org/0000-0003-3484-3869
}

\begin{abstract}
The composite concrete slab systems with steel-deck incorporated has become an alternative to conventional slab models, since it often does not require the use of shoring, promoting several constructive practices, beyond operation of the reinforcement as a positive moment. The procedure of verification of composite slabs is based on the semi-empirical method $\mathrm{m}$ and $\mathrm{k}$. The purpose of this paper was to investigate the application of the "m-k method" in a group of slabs with alternative dimensions as the usually adopted in the tests, even as to correlate the values obtained with the results found when testing the models as proposed by the ANSI 2011 test standard, since the normative method is costly and expensive. Therefore, four-point flexural tests were performed on slab models considering only one deck module, varying two spans, the same procedure was repeated in slabs with usual construction dimensions (normative models). The linear regression method was applied to the data found in order to obtain the parameters that would be analyzed. The main results show that the alternative model with the adopted dimensions does not present values that can be applied directly to the normative models, since the increase of the shear span reduces in a significant way the theoretical resistance of the slabs. Nevertheless, the values for the $m$ and $k$ obtained of both alternative and normative models can be adopted confidently as part of the sizing process of the respective models. The deviations between theoretical and experimental resistance satisfy the specifications of the ANSI 2011 standard for both models helped in the confirmation of the previous statement. The expectation of this paper is to assist in the search for new procedures for determining parameters $\mathrm{m}$ and $\mathrm{k}$.
\end{abstract}

Keywords: alternative and normative models, m- k method, longitudinal shear, composite slabs.

\section{Resumo}

O sistema de lajes mistas de concreto com fôrma de aço incorporada tem se tornado uma alternativa aos modelos de lajes convencionais, pois muitas vezes dispensa o uso de escoramentos, promovendo diversas praticidades construtivas, além do funcionamento da fôrma como armadura de momento positivo. O procedimento de verificação das lajes mistas está fundamentado no método semi-empírico $m-k$. Este documento buscou investigar a aplicação do "método $m-k$ " em um grupo de lajes com dimensões alternativas às usualmente adotadas nos ensaios, assim como correlacionar os valores obtidos com os resultados encontrados ao ensaiar os modelos conforme proposto pela norma de ensaio ANSI 2011, já que o método normativo é custoso e oneroso. Para tanto, foram realizados ensaios à flexão de quatro pontos em modelos de lajes considerando apenas um módulo de "deck", variando dois vãos; o mesmo procedimento foi repetido nas lajes com dimensões usuais de construção (modelos normativos). Aplicou-se o método de regressão linear nos dados encontrados a fim de obter os parâmetros que seriam analisados. Os principais resultados encontrados demonstram que o modelo alternativo não apresenta valores que possam ser aplicados aos modelos normativos, uma vez que o aumento do vão de cisalhamento reduz de forma significativa a resistência teórica das lajes. Porém os valores obtidos para $m$ e $k$, tanto dos modelos alternativos, quanto normativos, podem ser adotados confiadamente como parte do processo de dimensionamento dos respectivos modelos. Os desvios entre a resistência teórica e experimental satisfazem as especificações da norma ANSI 2011 para ambos os modelos auxiliando a confirmação da afirmação anterior. Espera-se com esse trabalho auxiliar a pesquisa de novos procedimentos para determinação dos parâmetros $m$ e $k$.

Palavras-chave: modelos alternativos e normativos, método $m-k$, cisalhamento longitudinal, sistema misto. 


\section{Introduction}

The composite slab systems consist of a steel profield cold formed associated with the concrete. The composite behavior of slab is configured when the steel profield and the concrete, in the hardened state, if connect forming a single structure element. The interaction between cold formed profile and concrete cape was must be capable of transmitting forces at the interface being responsible for the effectiveness of the composite system. The geometry of the cross-section of the steel form and the arrangement of the dents surface slabs directly influence the structural behavior of the composite slabs, since the dents present on the form surface are fundamental for the mechanical connection between the concrete cape and the steel deck, Baião Filho [1]. The forces developed at the interface are main responsible for breaking this mechanical connection between the profield cold formed and the concrete cover. Currently, two methods are usually adopted to verify the interface shear strength of this system, which are the partial interaction method and the semi-empirical method $m-k$, which is the most used and main object of study of this work.

The use of the composite concrete slab systems with steel-deck incorporated requires a good comprehension of the behavior of the materials that compose the slab as well as the mechanical properties that guide it. Considering the usual profiles and spans, this system has a predominant collapse mode, the longitudinal shear, and it is necessary to use the methods mentioned above to calculate its resistant capacity. The " $m-k$ method" consists in obtaining two sizing parameters, angular $(m)$ and linear $(k)$ coefficients of a line constructed from a semi-empirical equation that relates the nominal shear strength resistance with parameters obtained in the test. A variation of the application of the commonly used " $m-k$ method" was proposed and developed in this work: the investigation and validation of the method applicability in models with only one deck
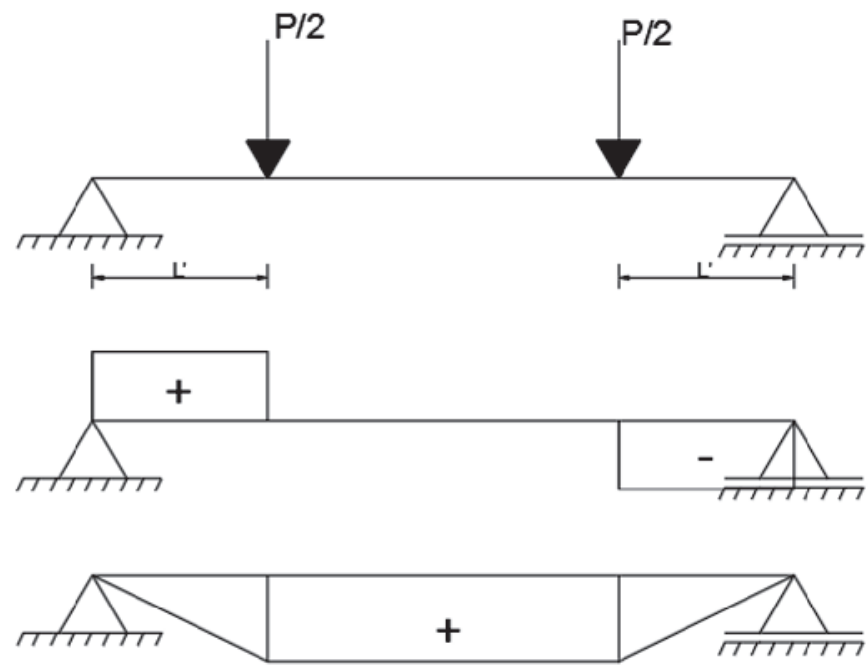

\section{Figure 1}

Four point bending test model with shear and bending diagrams

Source: The Author module, observing the representativity of the values found when compared with the test values whose models are in accordance with the proposition of the ANSI standard [2]. As this is a new application of the "m-k method", it became necessary to correlate and compare the results and behaviors presented with those that occur in the application of the method to models proposed by norm, with purpose of verify the validity of the application of the results before models of different geometric characteristics. Several researchers have evaluated the influence of longitudinal shear on the composite system, based on normative scale models submitted to the four-point bending test. This test consists of submit a sample to the action of two concentrated loads of the same intensity, equidistant from the supports, where the region of the sample between the load and the support is submit to bending and shear forces while the region between the loads is subjected to pure bending (figure 1). Regarding the research done, Abdullah \& Easterling [3] proposed a new method to model the horizontal shear connection in composite slabs; Campos [4] evaluated the effect of continuity in composite slabs; Costa [5] analyzed the influence of friction on the supports in the calculation of longitudinal shear strength. There are also studies on smaller scale models, such as the work of Daniels \& Crisinel [6], which developed a numerical method of analysis that only requires push-off and pull-out shear tests. Although existing literature proposes that short and big height composite slabs can transfer loads directly to the supports, according to the connecting rod and tether pattern, and that extrapolation of results may against to safety values, Johnson \& Anderson [7], it was not possible for the authors to find analysis and experimental results to secure these statements. Considering the research already carried and the above mentioned, it is intended in this work, as an unprecedented proposal of study, to analyze the longitudinal shear in composite slabs with alternative dimensions to those commonly used, submitting them to the four-point bending test, thus obtaining, values for the $\mathrm{m}$ and $\mathrm{k}$ parameters, verifying their application viability. Another objective also sought will be the extrapolation of its results to larger models, seeking to prove whether or not this extrapolation is viable.

\subsection{Longitudinal shear strength of "steel deck" slabs}

Several studies have shown, from semi-empirical procedures, that composite systems concrete slab with steel-deck incorporated, considering the usual profiles and spans, has a predominant mode of collapse, the longitudinal shear. Its occurrence is conditioned to a series of factors involving the geometrical characteristics such as: the embossing of the forms and the presence of superficial dents and indentations that help in the improvement of the mechanical connection. The yield strength of steel has little influence on occurs or not in that collapse mode. According to Araújo [8], the longitudinal shear strength allows full plastification of the maximum moment section only if complete interaction between the concrete and the steel form occurs, and then the flexural collapse occurs. On the other hand, if shear connection is not sufficient to promote complete interaction, slab collapse will occur by longitudinal shear. Seleim \& Schuster [9] showed that the process of development of longitudinal shear collapse occurs gradually. Initially, when the shear 
transfer devices are no more capable of transferring all the longitudinal stress, cracking will begin at the critical point, a factor responsible for increasing the stress difference between concrete and steel deck, causing the crack propagation. The concrete slab and steel deck then begin to separate, decreasing the efficiency of the embossing and, consequently, the significant relative edge slippage between concrete and steel form begins. Thereafter, cracking and edge slippage are increased until complete failure of the transfer devices when the system will no more be able to withstand increased load.

A composite system may have all or partial shear interaction. The total shear interaction is defined according to EUROCODE 4 [10] when the increase in longitudinal shear strength no more corresponds to the increase in bending moment strength. Otherwise, the shear interaction will be partial. Except in situations where the shear gap is exceptionally large, the collapse of the composite system of steel and concrete will occur by longitudinal shear.

The solution usually adopted to verify the resistant capacity of the composite system consist in accomplishment on the laboratory testing program with models single-span under bending using the semiempirical method $m-k$, as proposed by the ANSI standard [2], through equation (1) in the linear regression process of the test results.

$V u t=b \cdot d_{f}\left(m \frac{1}{L^{\prime}}+k\right)$

Being,

$V_{u t}$ the total last transverse shear obtained in the tests at Newton for $1000 \mathrm{~mm}$ of slab width;

$b$ the width of the slab in $\mathrm{mm}$;

$d_{f}$ the effective height of the slab in $\mathrm{mm}$;

$L^{\prime}$ is the shear span in $\mathrm{mm}$;

$m$ and $k$ are the parameters obtained in the linear regression process, in $\mathrm{N} / \mathrm{mm}$ and $\mathrm{N} / \mathrm{mm}^{2}$, respectively.

Schuster [11], by establishing the original equation that gave rise to the formulation (1), verified the validity of the suggested equation by varying the geometric characteristics of the forms. In the first series of tests him fixed the thickness by varying the type of deck, dents and geometries. It was observed that neither the reinforcement rate nor the compressive strength of concrete has significant influence on the longitudinal shear strength of the followed models. The equation (1), recommended by the ANSI standard [2], has two unknown variables, $m$ and $k$. Rewriting it as the equation of a straight line, is possible, from the linear regression of the test data, obtain the two unknown variables:

$Y=m X+k$

$Y=\frac{V u t}{b d f}$

$X=\frac{1}{L^{\prime}}$

It is relevant to clear that the data processing method proposed by the ANSI standard [2] differs in some aspects from the proposition made by ABNT NBR 8800 [12], which adopts the EUROCODE 4 equation [10]. The equations adopted in the linear regression process to obtain $m$ and $k$ adopting different geometric parameters between the two standards. The units of measurement of $m$ and $k$, presented by ABNT NBR 8800 [12], are given in units of stress, as presented in equation (5), while in ANSI [2] they are given in units as presented previously.

$V_{l, R}=b d_{f}\left[\left(\frac{m A_{F, e f}}{b L_{s}}\right)\right]+k$

Using the same equation (2), the variables $X$ and $Y$ are given by equations (6) and (7), respectively:

$Y=\frac{V_{l, R}}{b d f}$

$X=\frac{A F_{e f}}{b L_{s}}$

Where,

$V_{1 R}$ The resistant longitudinal shear force, given Newton, of the steel profile incorporated slabs relative to $1000 \mathrm{~mm}$ in width;

$\mathrm{b}$ the width of the slab in $\mathrm{mm}$;

$d_{f}$ is the distance from the upper face of the concrete slab to the geometric center of the effective section of the form expressed in $\mathrm{mm}$; $L_{\mathrm{s}}$ is the shear span in $\mathrm{mm}$;

$m$ and $k$ are the parameters obtained in the linear regression process; $A_{F, \text { ef }}$ the area of the effective section of the form.

It is easy to observe, by equation (7), that the geometric variations present in the form, resulting from the embossing process, directly influence the obtainment of the $m$ and $k$ parameters, since the cross section area is inversely proportional to the angular coefficient of the straight, in other words, the greater the area, the smaller it is angular coefficient $m$, unlike equation (4), where the cross section area of the form is not considered in the linear regression equation.

Beyond of the equations that define the strength of the composite slab system, it is important to emphasize its possible collapse modes. According to Brendolan [13], the collapse of the bending slab system is similar in nature to that of conventional reinforced concrete beams, differing only in the cold formed steel that provides the positive reinforcement. The bending collapse can be considered critical only when there is all interaction to shear at the interface between the metal deck and concrete cape, which occurs when have long spans and small slab thickness with high efficiency of the form dents, so that the shear force at the interface is not greater than the connection strength. Otherwise there will be no complete interaction and slab collapse is defined as longitudinal shear.

Vertical shear collapse occurs only in special cases of thick slabs with very short spans or by the application of high concentrated loads near the supports. The collapse by puncture occurs in cases

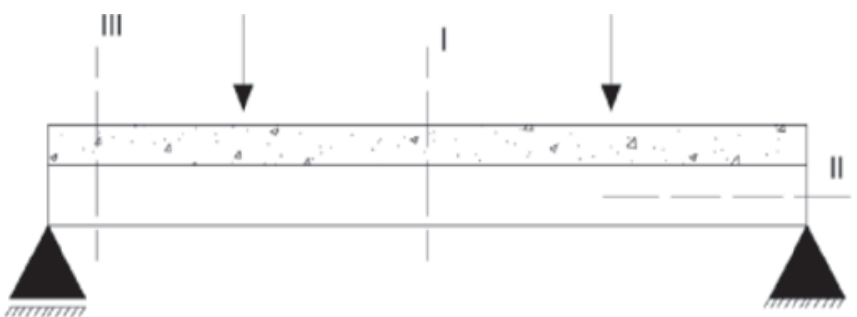

\section{Figure 2}

Composite system colapse modes

Source: SIEG, 2015, p. 30 
Table 1

Geometric characteristics of the specimens tested

\begin{tabular}{ccccc}
\hline \multicolumn{5}{c}{ Geometric characteristics } \\
\hline Specimens & CP01 & CP02 & CP03 & CP04 \\
b (mm) & 19.82 & 21.01 & 20.87 & 19.33 \\
Lo (mm) & 50.00 & 50.00 & 50.00 & 50 \\
Lc (mm) & 140.00 & 140.00 & 140 & 140 \\
t (mm) & 0.914 & 0.924 & 0.934 & 0.914 \\
Lt (mm) & 251.35 & 251.96 & 250.98 & 250.87 \\
So $\left(\mathrm{mm}^{2}\right)$ & 18.12 & 19.41 & 19.49 & 17.67 \\
\hline
\end{tabular}

Source: The Author

where high loads are concentrated in small areas, as in the case of pillars that born on the slab.

The collapse by longitudinal shear, among the others presented, if highlight for being the that occurs more frequently, being characterized by the formation of a crack by diagonal stress under or near one of the load points followed by relative slippage edge resulting in loss of system load capacity. Johnson [14] presents the three modes of collapse as can be seen in figure 2: section I (bending), section II (longitudinal shear) and section III (transverse shear). Another fundamental feature to be observed for composite slabs is the influence of friction on the support region. Studies show that in models with relatively short shear spans, the influence of friction on the supports is relevant in the calculation of longitudinal shear strength, since smaller spans promote greater reaction on the supports. The intensity of the vertical force produced increase the mechanical contact between metal deck and concrete cover, making it difficult to slippage between them. This causes an increase in the force required for relative slippage and a total or partial loss of mechanical interaction. This effect is reduced when mean to larger spans, precisely because the contact force between concrete cover and steel deck, is reduced, facilitating the occurrence of relative slippage that occurs for lower force values. The $m-k$ method doesn't take this effect directly into account and is implicit in the experimental results.

\section{Experimental analysis of normative and alternative systems}

The use of the incorporated steel profiles composite slab system requires a good understanding of the behavior of the composing materials as well as the mechanical properties that characterize it. This system has a predominant collapse mode, longitudinal shear, which requires its design to use a very widespread method, the semi-empirical method $\mathrm{m}-\mathrm{k}$, whereby it is possible to establish the resistant capacity of the composite slab.

The test proposed by the ANSI standard [2], adopted as a reference in this work, establishes the means that must be followed to evaluate the behavioral and quantitative relationship between slabs with different steel deck thickness and span. According to her, when a number of different deck thicknesses are produced for the project and only the smallest thickness is used in the test program, a minimum of four tests should be performed: two for a larger shear span and two for a smaller, this is the procedure adopted here to perform the experiments. The deck thickness made in the test program of this work was $0.8 \mathrm{~mm}$, the other geometric characteristics were defined based on the design and testing needs.

\subsection{Characterization of steel deck}

The characterization of the steel deck consisted of the testing of four specimens following the standards specified by ABNT NBR 6892 [15]. The standard proposes that the dimensions of the specimen can be defined by considering the original metallic product, as well as it's cross section that can be square, rectangular, circular, among other shapes. It can therefore be subdivided into two groups: proportional and non-proportional. For this work, was chosen to use the non-proportional specimen, where the original measurement length $\left(L_{0}\right)$ is independent of the original cross section area $\left(S_{o}\right)$. As of the normative references, the dimensions of the specimens were measured, the thickness of the zinc cover was removed and the results found in Table 1 were presented.

As a consequence of the test performed, it was possible to determine the stress strength, $f u(\mathrm{MPa})$, of the steel used to manufacture the steel deck (Table 2). During the procedure the real thickness of the steel was taken into consideration, disregarding the galvanization thickness of $0.04 \mathrm{~mm}$. Due to variations in specimen dimensions and rupture loads, the mean stress value was accepted. The yield strength of the steel profile could not be obtained. Thus, the plastification located in the form that may appear in the assays can only be qualitatively evaluated.

\subsection{Characterization of concrete}

The concrete used to mold the slabs was produced by a concrete batching plant with characteristic strength, $f_{c k}$, estimated at $30 \mathrm{MPa}$ after 28 days. Prior to the start of concreting, cylindrical specimens of 100 by $200 \mathrm{~mm}$ were molds; 3 specimens for axial compression test according to ABNT NBR 5739 specifications [16] and 4 specimens for determination of the modulus of elasticity using the test practice specified by ABNT NBR 8522 [17], whose results are presented in table 3.

\section{Method}

\subsection{Alternative models consisting of only one steel deck module}

The composite concrete slab systems with steel-deck incorporated,

\section{Table 2}

Mechanical properties of the steel deck

\begin{tabular}{|c|c|c|c|c|c|}
\hline \multicolumn{6}{|c|}{ Steel deck tensile test results } \\
\hline Specimens & CP01 & CP02 & CP03 & CP04 & Middle \\
\hline $\begin{array}{l}\text { Rupture load } \\
(\mathrm{kN})\end{array}$ & 4.94 & 5.10 & 5.48 & 4.16 & 4.92 \\
\hline $\begin{array}{l}\text { Rupture stress fu } \\
(\mathrm{MPa})\end{array}$ & 272.62 & 262.75 & 281.17 & 235.42 & 262.99 \\
\hline $\begin{array}{l}\text { Yield stress fy } \\
\text { (MPa) }\end{array}$ & & & 180 & & \\
\hline $\begin{array}{l}\text { Elasticity module } \\
\text { (MPa) }\end{array}$ & & & 200000 & & \\
\hline
\end{tabular}


Table 3

Axial compression resistence (MPa) and concrete Elasticity Module (Mpa)

\begin{tabular}{ccccc}
\hline & Steel deck tensile test results & & \\
\hline Specimens & CP01 & CP02 & CP03 & Middle \\
Axial compression strength & 36.12 & 38.63 & 45.64 & 40.13 \\
$(\mathrm{MPa})$ & - & - & - & 21.88 \\
\hline $\begin{array}{c}\text { Elasticity module } \\
(\mathrm{GPa})\end{array}$ & - & - & \\
\hline
\end{tabular}

Source: The Author

considering only one module steel deck, proposed as comparative to the normative scale model, has its length and width previously defined, for installation the test "setup" on the press used. Some limitations for the development of the trial, such as maximum dimensions of the press were responsible for choosing the dimensions of alternative models, especially their length. Height was establish, based on what was determined for the normative model, so that it allowed to analyze the dimensional compatibilities and incompatibilities came by to influence the comparative between the results obtained in both, the alternative and the normative model. The alternative composite system was then defined by a trapezoidal steel deck module with a nominal thickness of $0.8 \mathrm{~mm}$ and a height of 75 $\mathrm{mm}$, a width of $350 \mathrm{~mm}$ and a length of $700 \mathrm{~mm}$.

In addition to the steel deck, the model is made up of a $65 \mathrm{~mm}$ thick normal density concrete cover, specified $30 \mathrm{MPa}$ fck, and welded steel mesh to restrict crack propagation and retraction during the curing process. It has $3.8 \mathrm{~mm}$ in diameter and $15 \mathrm{~cm}$ of wire spacing. The mesh was positioned in the region above the elastic neutral line of the cross section, ensuring, especially in alternative models, that the tensile stresses imposed on the specimen during the bending test were resisted only by the steel deck without participation of the metallic mesh. The nomenclature adopted for the models was: RM75-NI. Being RM, the steel deck manufacturer's, 75 the height of the deck and NI indicates that the position of the center table of the deck module is below its center of gravity. For the execution of the normative and alternative models, the use of stiffened U-type steel profile with specific width, thickness and lengths was adopted to delimit the slab dimensions (figure 3), which were removed before the tests. All models, normative and alternative, were supported only at the edges during their execution, allowing them to deform along the span during concreting. The instrumentation of the models was basically composed of lin-
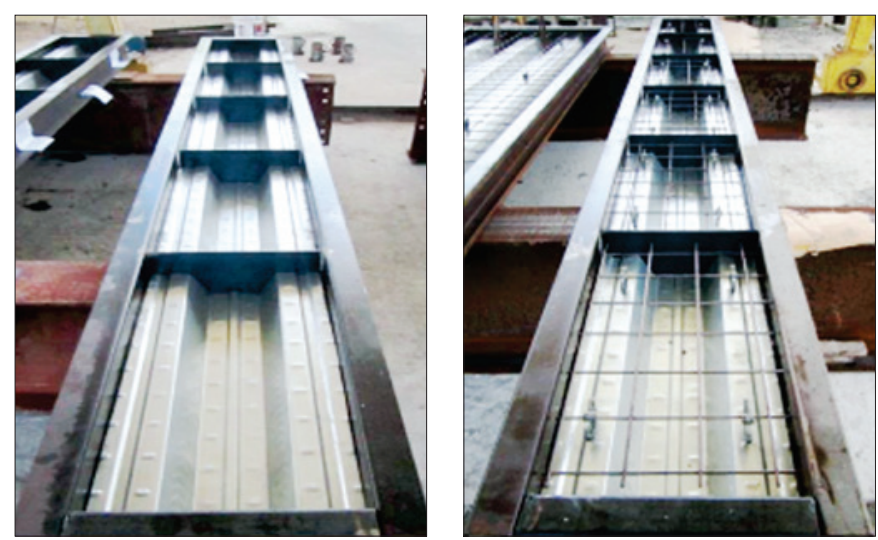

\section{Figure 3}

Mounted forms for the concreting; mold and shape for embedding

Source: The Author ear displacement measuring transducers (LVDT'S) with the objective of measuring the mid-span displacement and the relative edge slippage, besides the use of strain gauge to measure the state of deformation in the steel deck and concrete cover.

The test developed first in the $600 \mathrm{~mm}$ span specimens group followed by the $500 \mathrm{~mm}$ specimens group. The test was performed in sequential loading steps. First, $5 \%$ of the expected last load $\left(\mathrm{W}_{t}\right)$ was applied and maintained for a period of 5 minutes. Then the loading was removed and all measuring instruments zeroed. The same procedure was done for a load of $60 \%$ of the expected last load $\left(\mathrm{W}_{t}\right)$. After five minutes, the load was removed, all instruments zeroed and the specimen "rested" for 2 minutes. The final loading step was then initiated, entail the specimen to collapse. This was done for all specimens in each group. Figure 4 demonstrate the loading layout adopted in the test of alternative models.

\subsection{Normative slabs models}

Before presenting the dimensions adopted for the normative models, it is important to clarify that the L' shear span adopted for the composite concrete slab systems with steel-deck incorporated should be equivalent to $1 / 4$ of the theoretical slab span; This specification is justified by the fact that the test is done by applying two equidistant concentrated loads of the supports. However, when designing the composite system, loading is considered to be evenly distributed throughout the span of the slab. The equivalence between the two conditions is obtained by equality of the area underneath the shear stress diagram for evenly distributed load situations with the area

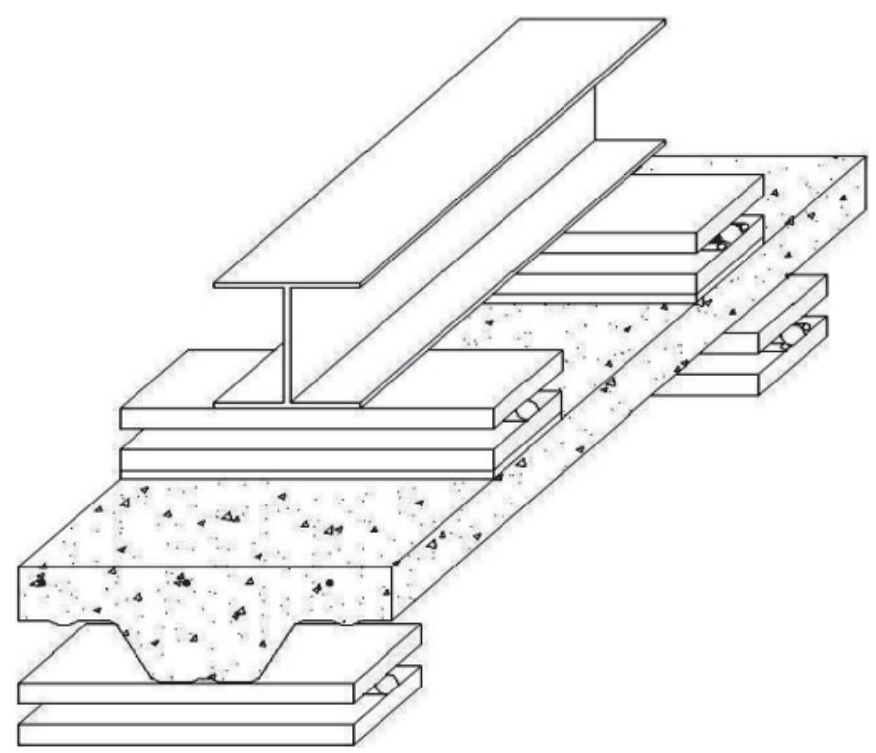

Figure 4

Alternative model load scheme

Source: The Author 
underneath the shear stress diagram for symmetrically arranged concentrated loads, yielding the same maximum shear force value.

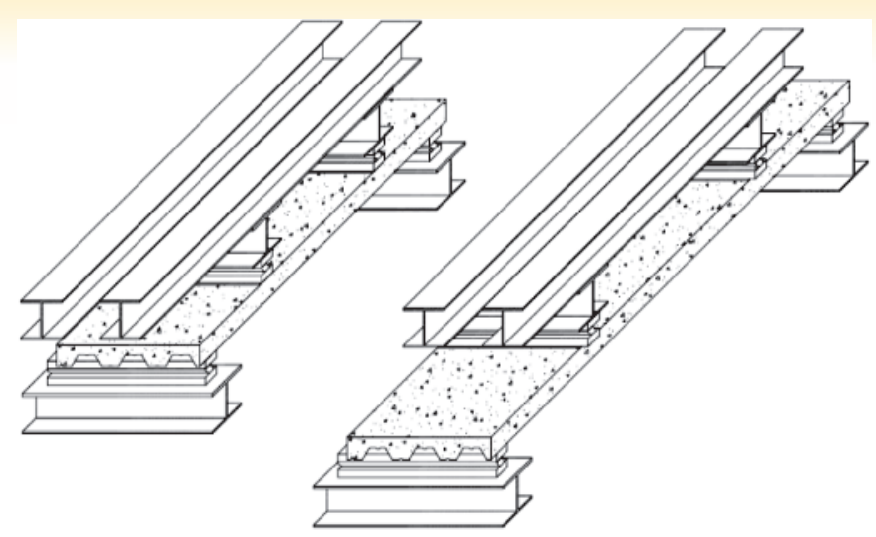

Figure 5

Normative model load scheme

Source: The Author
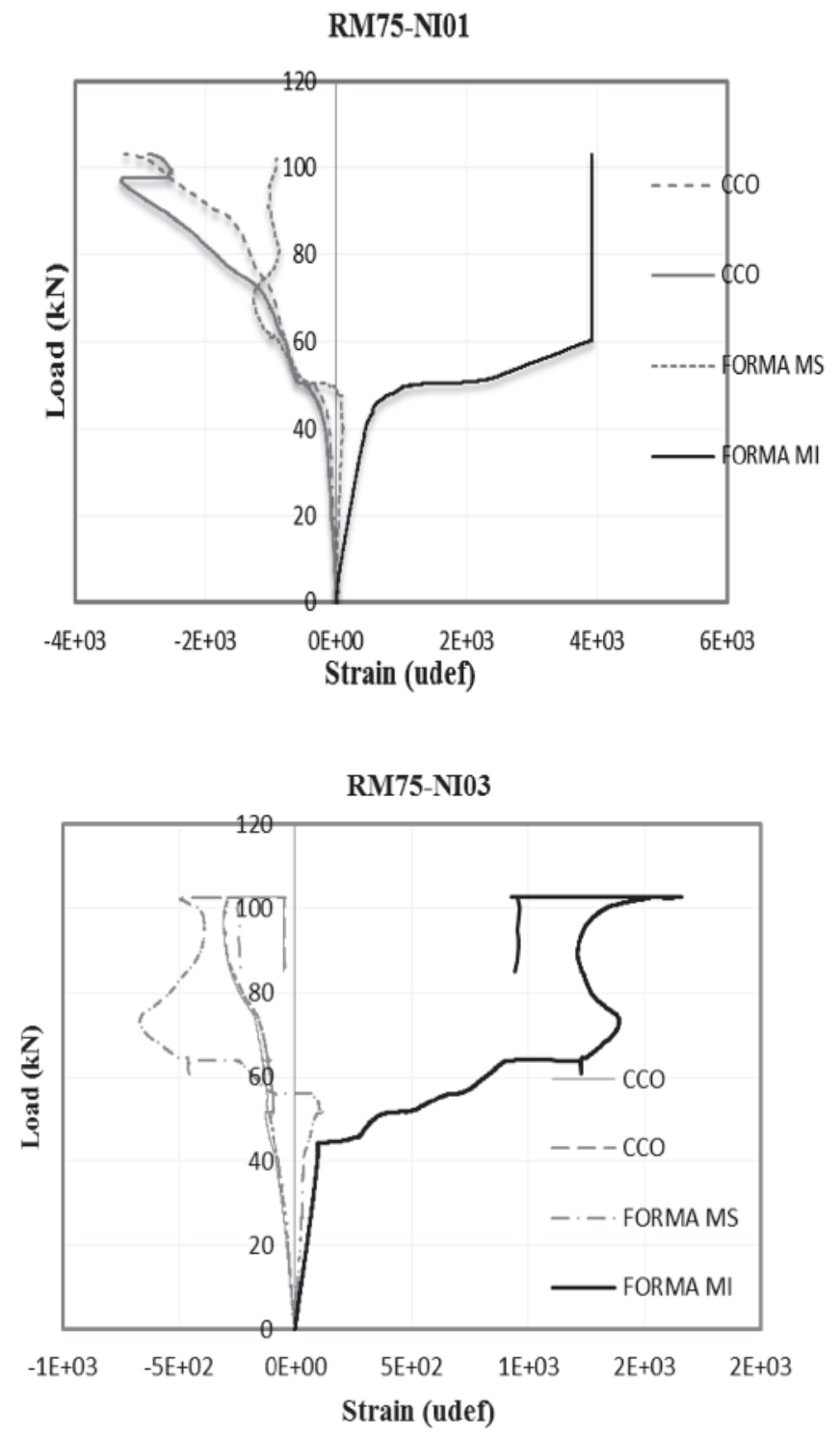

Figure 6

Load $x$ Strain of the specimen RM75-NI 01 to 04

Source: The Author
For the normative composite system tested in this work, the spans that are conventionally adopted in the construction processes with the RM 75 deck were defined. Two values for the spindle-to-spindle span were then adopted, these values being $2 \mathrm{~m}$ and $3 \mathrm{~m}$. The nomenclatures adopted for specimens with these dimensions were defined as RM75-02 and RM75-03 respectively. Other geometrical characteristics, such as the deck thickness $(t)$ and the width $(b)$ of the model, were fixed by the choice of the deck as already mentioned in the "alternative model". The total height $\left(h_{t}\right)$ of the slab was defined from the behavior presented by the steel profile for the concrete phase in the fresh state; under these conditions, it was possible to establish the steps measurements of the two normative models necessary to determine the parameters $m$ and $k$. Thus, the adopted normative composite system is formed by a trapezoidal section steel profile with a nominal thickness of $0.8 \mathrm{~mm}$ and a height of $75 \mathrm{~mm}$, width of $911 \mathrm{~mm}$. These characteristics are defined by the manufacturer during the mechanical forming of the steel deck. The normal density concrete cover has a thickness of $65 \mathrm{~mm}$ and a specified fck of $30 \mathrm{MPa}$. The mesh used has a diameter of $3.8 \mathrm{~mm}$, being positioned $20 \mathrm{~mm}$ below the upper face of the slab, ensuring
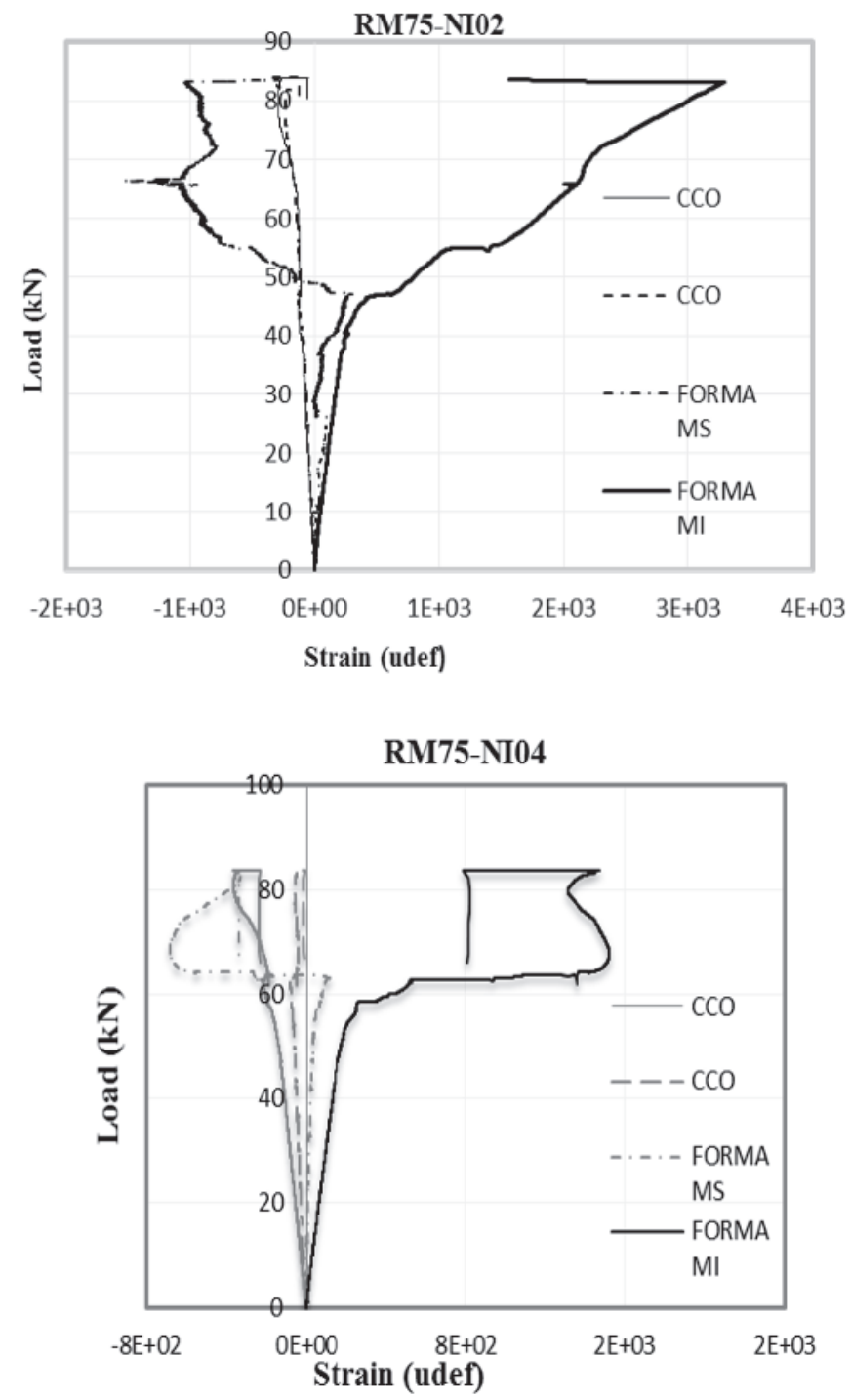
its minimum coverage, besides being above the neutral line elastic, so that it doesn't participate in the resistance to tensile stresses arising from bending during the test run. The slabs of the normative models had strain gauges positioned on the concrete surface and of the steel profile as done with the alternative models. On the concrete surface were two strain gauges positioned in the center of the span, symmetrically disposed in relation to the lateral edge of the slabs. The other two, were similarly positioned in the center of the slab, one in the upper flange and the other in the lower steel deck flange. Displacement and relative slip measurements were made using indicator; two positioned in the middle of the span, on opposite sides of the slab edge and another positioned on the front face, attached to a magnetic base, which was fixed in the steel deck and the indicator cursor pressed against the concrete cover. Thus it was possible to follow whether or not there was relative slippage and the value of the load acting at this moment, besides measuring its maximum value until the collapse.
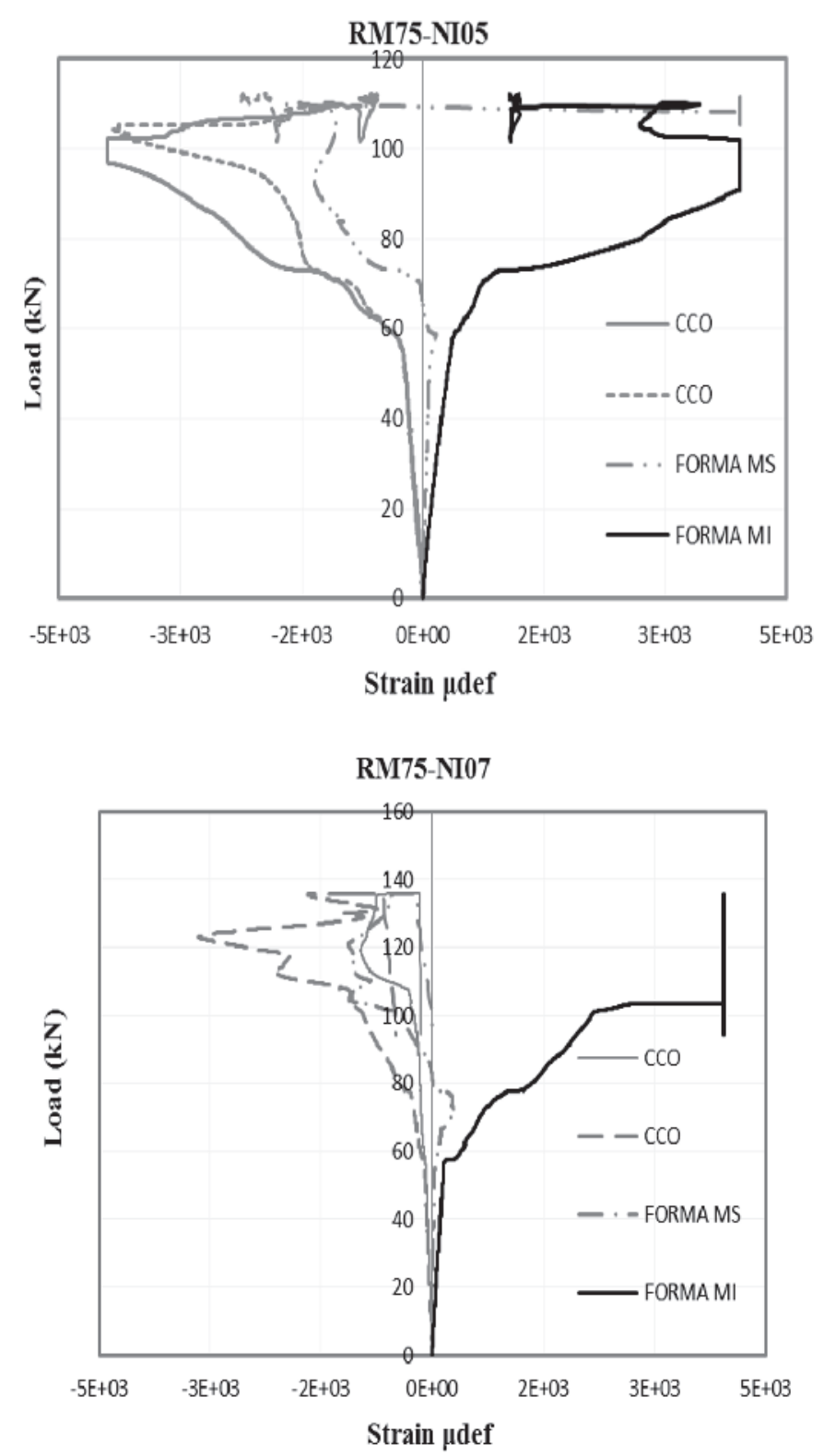

\section{Figure 7}

Load x Strain of the specimen RM75-NI 05 to 08

Source: The Author
The evaluation of the normative slabs was carried out in compliance with most of the procedure proposed by ANSI standard [2], but the loading process was similar to the one carried out in a static load test, where the static forces were increasingly applied recording the displacements corresponding to each applied load value (Figure 5).

\section{Results}

\subsection{Alternative models composed of a deck module}

The graphs obtained in the tests of figures 03 and 4 exhibit the deformations measured in the RM75-NI specimen. The results indicate that the highest stress values, as expected, occurred at the extremities of the cross section of the models. The stress in the lower flange of the steel deck were higher than those stress observed in its upper flange. Both flanges presented tensile stress
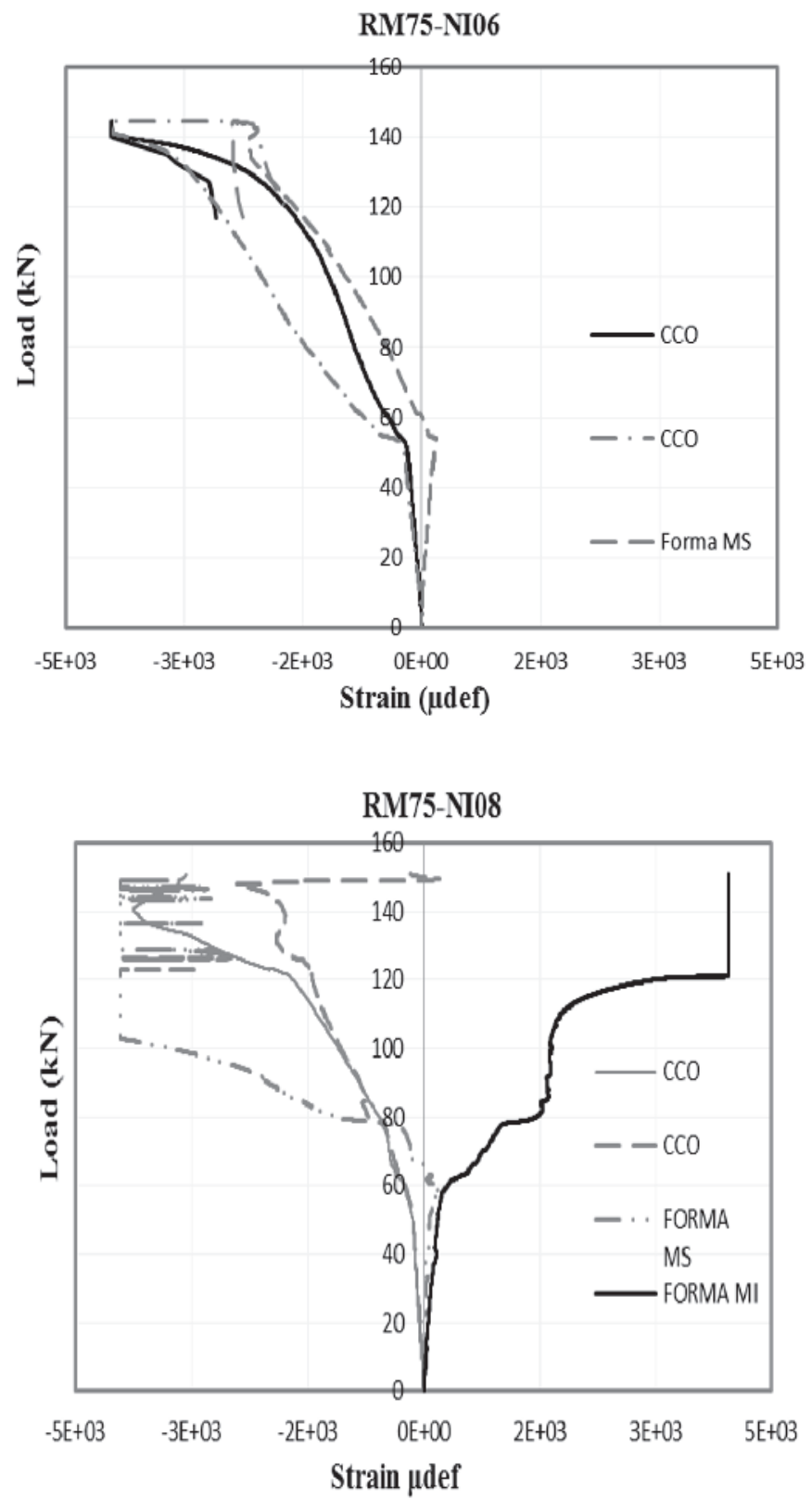
during basically the whole test, until partial plasticization of the composite section, when the upper flange began to suffer compressive stress. The tests confirmed the expected result that the deformations measured by the strain gauges positioned on the surface of the concrete cover were compression, as seen in figures 6 and 7. In these figures the symbols CCO, Form MI and Form MS mean: concrete cover, flange lower deck and upper deck flange respectively. The composite section has elastic behavior up to a load of $40 \mathrm{kN}$ and thereafter demonstrates inelastic behavior. The RM75-NI 01 and 02 specimens presented higher values of deformation until rupture if compared with the RM75-NI 03 and 04 specimens.

The difference in stiffness between steel and concrete in the interface zone of each model does not appear to influence their behavior while still in the elastic phase. It is possible to notice that the connection in the interface breaks after localized plasticization of the section, which can be noticed by the occurrence of plastic arrows and plastic deformations obtained by the strain gauges attached to the concrete cover and steel decks. It is possible to notice the relative slippage between the steel deck and the concrete cover, which characterizes a longitudinal shear failure. In addition, the change in tensile stress signal at the upper steel deck flange, for stress to compression, characterizes the formation of a second elastic line, typical behavior of partial interaction to longitudinal shear. Before, however, was observed the occurrence of cracks in the lower part of the cross section of the models in the region between the applied loads (pure bending region, null shear). The graphs indicated in figure 8 show that there was no wide variations between the elastic arrows of the RM75-NI 01 to 04 specimens subject to the same loading

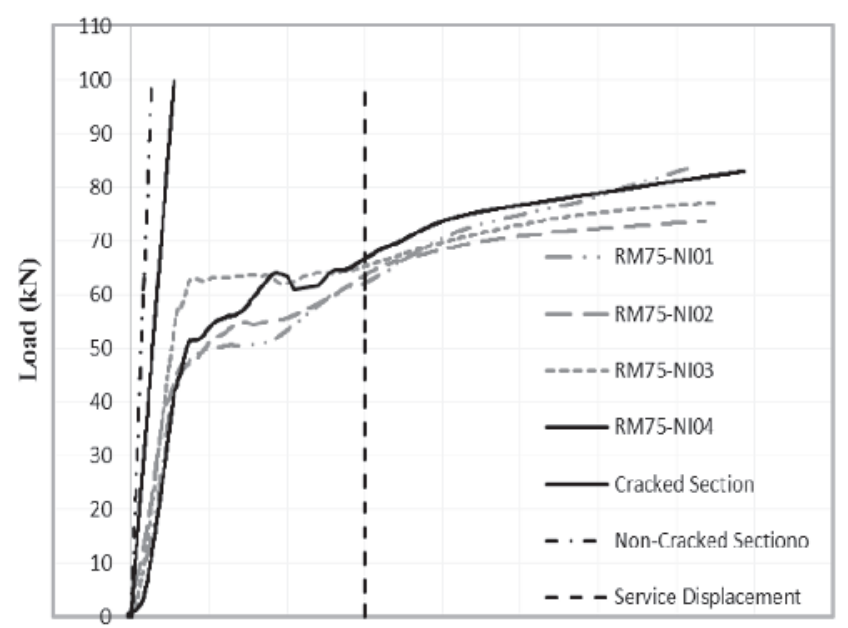

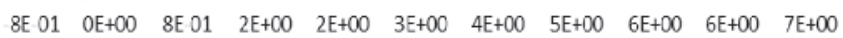
Displacement (mm)

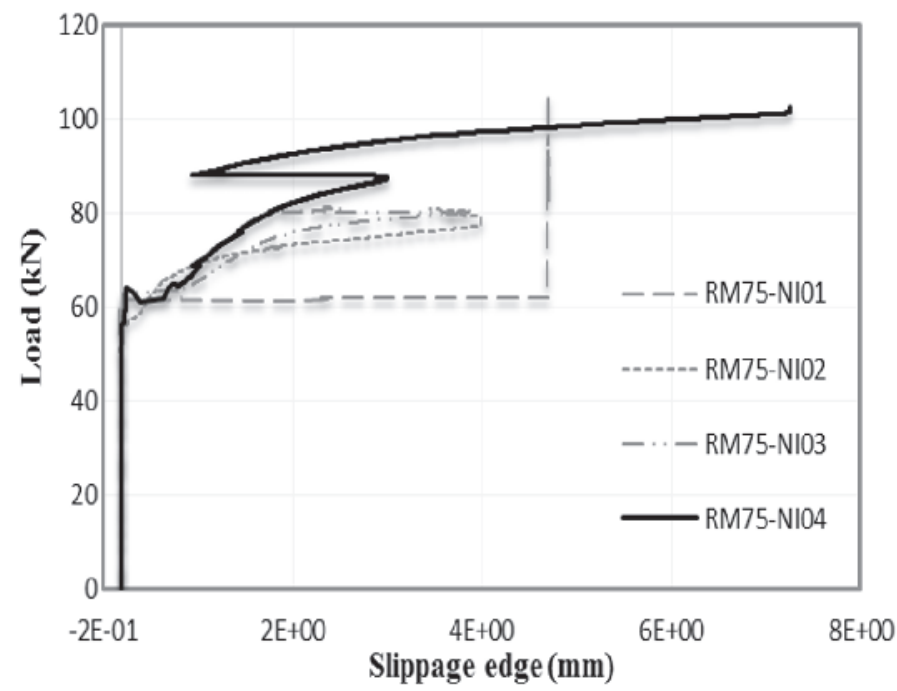

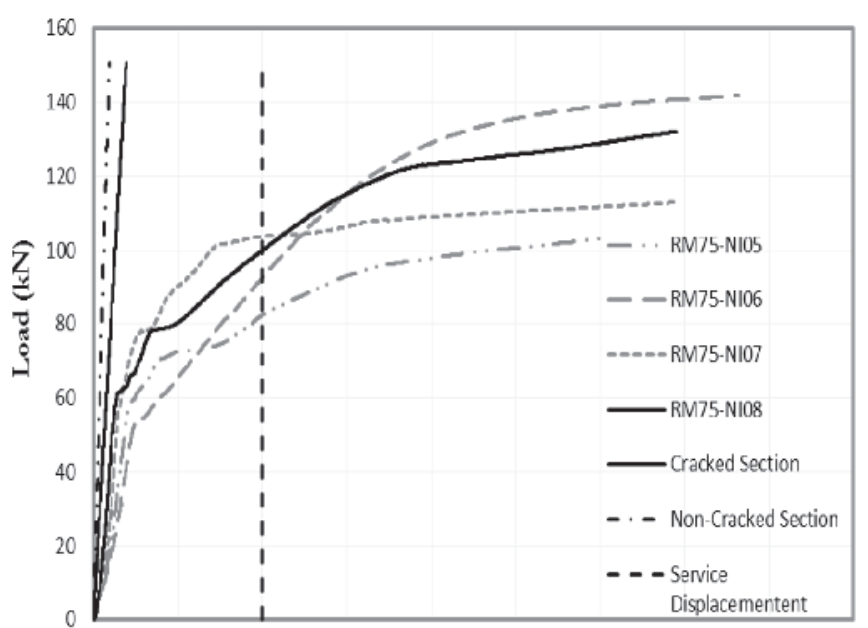

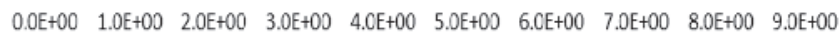
Displacement (mm)

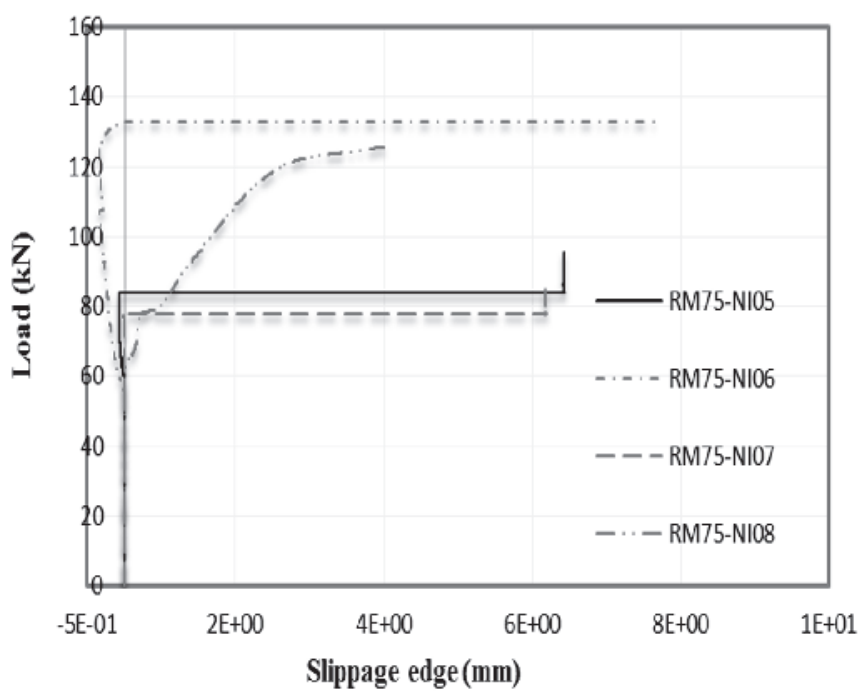

\section{Figure 8}

Load $x$ displacement in the mid span and load relative slippage of specimens RM75-NI

Source: The Author 


\section{Table 4}

Determination of transverse shear total finish of tests Vut

\begin{tabular}{lccccccccc}
\hline Specimens & $\begin{array}{c}\mathbf{b} \\
(\mathbf{m m})\end{array}$ & $\begin{array}{c}\mathbf{h t} \\
(\mathbf{m m})\end{array}$ & $\begin{array}{c}\mathbf{d f} \\
(\mathbf{m m})\end{array}$ & $\begin{array}{c}\mathbf{L} \\
(\mathbf{m m})\end{array}$ & $\begin{array}{c}\mathbf{L}^{\prime} \\
(\mathbf{m m})\end{array}$ & $\begin{array}{c}\mathbf{P} \\
(\mathbf{k N})\end{array}$ & $\begin{array}{c}\text { Pue } \\
(\mathbf{k N})\end{array}$ & $\begin{array}{c}\text { P. Pslab } \\
(\mathbf{k N / m})\end{array}$ & $\begin{array}{c}\text { Vut } \\
(\mathbf{k N})\end{array}$ \\
\hline RM75-NI01 & 352 & 143 & 126.618 & 600 & 150 & 104.84 & 105.26 & 2.563 \\
RM75-NI02 & 353 & 145 & 128.618 & 600 & 150 & 83.93 & 84.35 & 2.563 \\
RM75-NI03 & 355 & 148 & 131.618 & 600 & 150 & 83.79 & 84.21 & 2.563 & 42.445 \\
RM75-NI04 & 355 & 147 & 130.618 & 600 & 150 & 102.66 & 103.08 & 2.563 & 51.811 \\
RM75-NI05 & 356 & 145 & 128.618 & 500 & 125 & 112.27 & 112.69 & 2.563 \\
RM75-NI06 & 350 & 145 & 128.618 & 500 & 125 & 144.55 & 144.97 & 2.563 & 72.708 \\
RM75-NI07 & 353 & 146 & 129.618 & 500 & 125 & 135.88 & 136.30 & 2.563 & 68.375 \\
RM75-NI08 & 355 & 148 & 131.618 & 500 & 125 & 150.80 & 151.22 & 2.563 & 75.836 \\
\hline
\end{tabular}

Source: The Author

\section{Table 5}

Linear regression of datas

\begin{tabular}{|c|c|c|c|c|c|c|}
\hline Specimens & $\begin{array}{c}\mathrm{X} \\
(1 / \mathrm{mm})\end{array}$ & $\begin{array}{c}\mathrm{Y} \\
\left(\mathrm{N} / \mathrm{mm}^{2}\right)\end{array}$ & $\begin{array}{l}\text { Regression } \\
\text { of results }\end{array}$ & $\begin{array}{l}\text { Vus } \\
\text { (kN) }\end{array}$ & Vus/Vut & $\begin{array}{c}\text { Deviation } \\
(\%)\end{array}$ \\
\hline RM75-NIO1 & 0.0067 & 1.1869 & \multirow{4}{*}{$m=341.62$} & 46.195 & 0.873 & -12.67 \\
\hline RM75-NIO2 & 0.0067 & 0.9349 & & 47.058 & 1.109 & 10.87 \\
\hline RM75-NIO3 & 0.0067 & 0.9069 & & 48.428 & 1.143 & 14.28 \\
\hline RM75-NIO4 & 0.0067 & 1.1174 & & 48.060 & 0.928 & -7.24 \\
\hline RM75-NI05 & 0.0080 & 1.2355 & \multirow{4}{*}{$k=-1.241$} & 68.314 & 1.208 & 20.76 \\
\hline RM75-NIO6 & 0.0080 & 1.6151 & & 67.163 & 0.924 & -7.63 \\
\hline RM75-NIO7 & 0.0080 & 1.4944 & & 68.265 & 0.998 & -0.16 \\
\hline RM75-NI08 & 0.0080 & 1.6230 & & 69.711 & 0.919 & -8.08 \\
\hline
\end{tabular}

Source: The Author

layout, in the specimens 05 to 08 , which may be an indication that there was no wide variation in the elasticity modulus of the concrete used. The elastic arrow occurs until a loading of the order of $40 \mathrm{kN}$, starting to present inelastic behavior. The allowable service arrow L / 250 and the theoretical arrows for cracked and non-cracked stages are also shown in this figure. The theoretical arrows of the cracked and non-cracked section approach the experimental arrows only at the initial load values. The service arrow was reached by the models already in the inelastic phase. The ductile behavior of the specimens can be observed by the large displacements presented until the moment of rupture, even after composite section plasticization. The presence of the mesh seems to influence the resistant capacity of the models.

The determination of the $m$ and $k$ parameters of the alternative models were performed according to the process presented in tables 4 and 5 , based on the results obtained in the specimens tests with reference to the ANSI standard [2]. The straight obtained from the linear regression of the data is presented in figure 9.

\subsection{Normative slabs models}

The graphs shown in figure 10 exhibit higher tensile stress values in the lower flange of the specimens, while the concrete cover underwent compressive stress during all the test. It is also possible to observe that until the rupture is not noticed a chiseled change from the elastic phase to the inelastic phase, that is, there is an indication of the low interaction between steel deck and concrete cover since the collapse occurs before the plasticization of the composite section. The graph load $x$ displacement in the mid-span of specimen RM7502 and RM75-03 are shown in Figure 11. The theoretical arrow of the cracked section follows the behavior of the experimentally measured arrow in the case of specimen RM75-02, which is an indication that the section cracked theoretical stiffness approximates the real stiffness. The theoretical arrow of the non-cracked

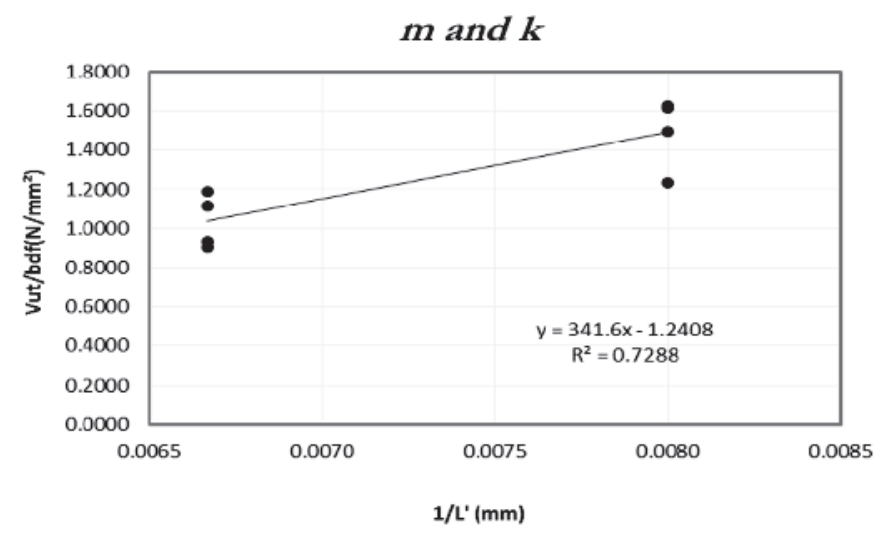

Figure 9

Linear regression of the test datesfrom alternative models

Source: The Author 

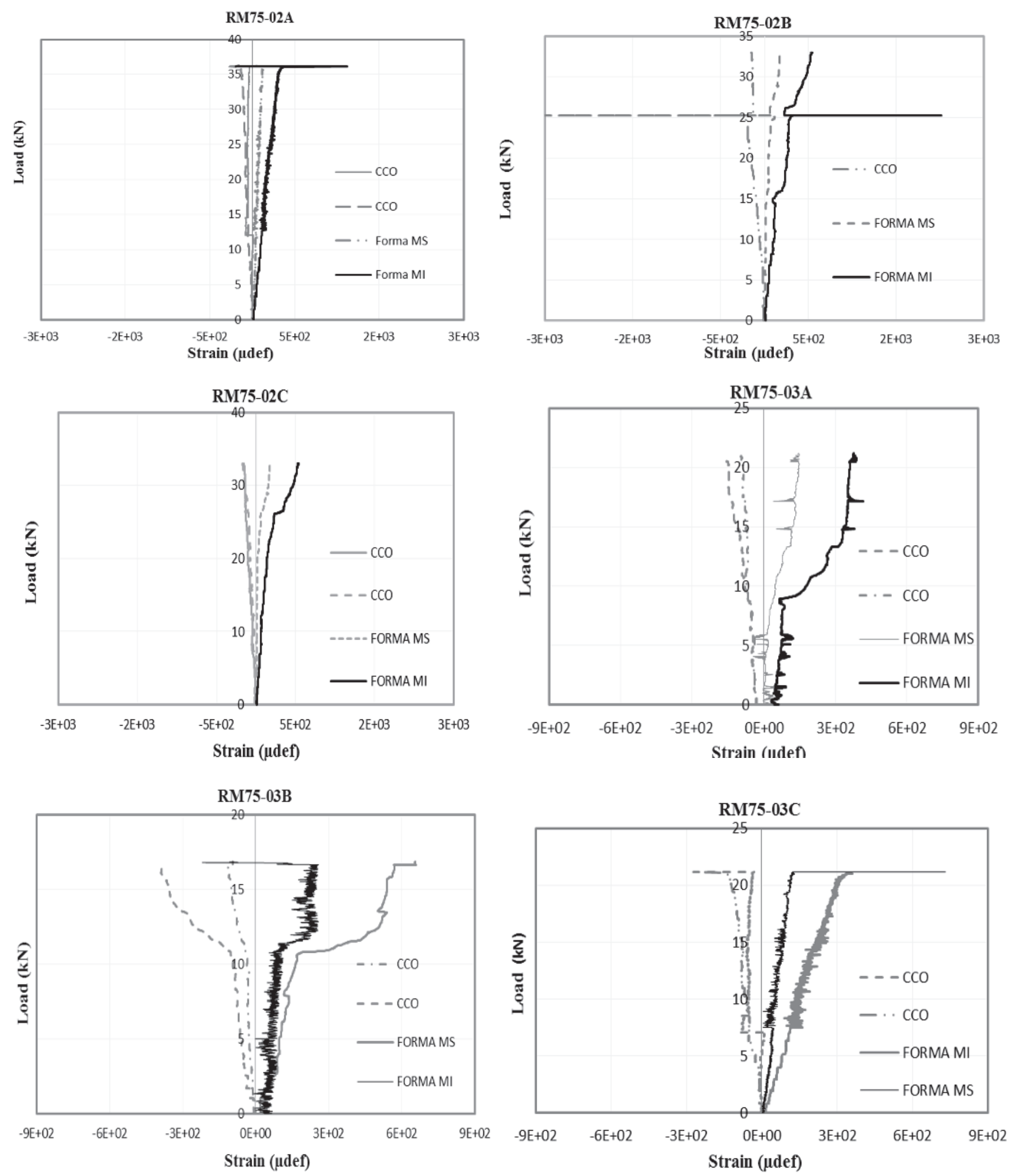

Figure 10

Load $x$ Strain of the specimen RM75 Normative models

Source: The Author 

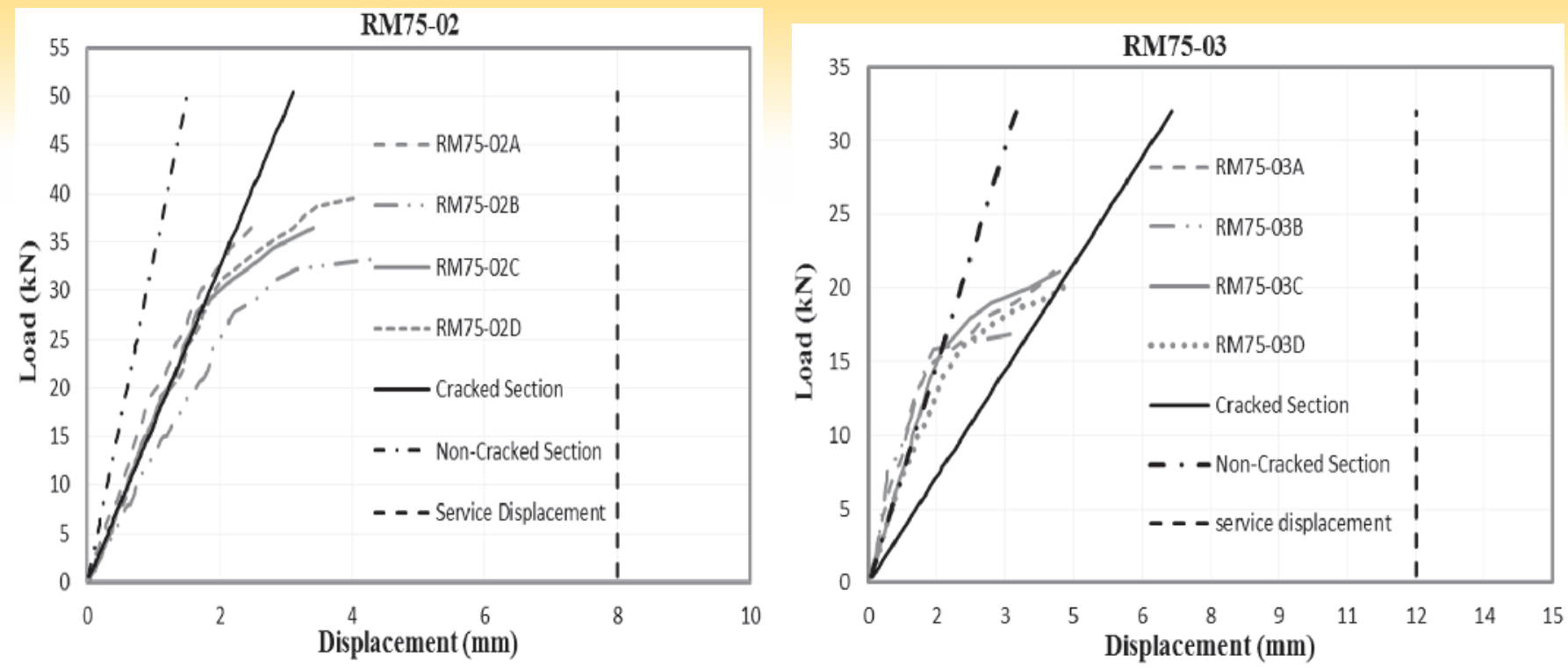

\section{Figure 11}

Load $x$ Displacement in the mid span of the specimens RM75 normative models

Source: The Author

section follows the experimental only in the initial load values. The RM75-03 specimens presented an arrow of the non-cracked section with similar behavior to the experimental, thus demonstrating that its initial stiffness compare the theoretical stiffness of the non-cracked section, in contrast to the RM75 02 specimen. The specimens of both groups reached collapse before reaching the service arrow.

The presence of the mesh, positioned in the compressed region of the cross-section, didn't demonstrate to significantly inhibit or assist the system's carrying capacity, since, by losing the interaction, even if partial, between the concrete cover and the steel deck, the system immediately collapsed.

The determination of the parameters $m$ and $k$ of these models was according to the specification of ANSI 2011 standard, as of linear regression of the data obtained in the test. This is presented in tables 6, 7 and figure 12 .

\section{Table 6}

Determination of transverse shear total finish of tests Vut

\begin{tabular}{|c|c|c|c|c|c|c|c|c|c|}
\hline Specimens & $\begin{array}{c}\mathbf{b} \\
(\mathrm{mm})\end{array}$ & $\begin{array}{c}\mathrm{ht} \\
(\mathrm{mm})\end{array}$ & $\begin{array}{c}\mathrm{df} \\
(\mathrm{mm})\end{array}$ & $\begin{array}{c}\mathrm{L} \\
(\mathrm{mm})\end{array}$ & $\begin{array}{c}\mathrm{L}^{\prime} \\
(\mathrm{mm})\end{array}$ & $\begin{array}{c}\mathbf{P} \\
(\mathrm{kN})\end{array}$ & $\begin{array}{l}\text { Pue } \\
(\mathrm{kN})\end{array}$ & $\begin{array}{c}\text { P. Pslab } \\
\left(k N / m^{2}\right) \\
\end{array}$ & $\begin{array}{l}\text { Vut } \\
(\mathrm{kN})\end{array}$ \\
\hline RM75-02A & 906 & 142 & 125.618 & 2000 & 500 & 36.200 & 41.828 & 2.563 & 23.232 \\
\hline RM75-02B & 913 & 137 & 120.618 & 2000 & 500 & 32.986 & 38.606 & 2.563 & 21.643 \\
\hline RM75-02C & 904 & 143 & 126.618 & 2000 & 500 & 36.208 & 41.828 & 2.563 & 23.231 \\
\hline RM75-02D & 905 & 141 & 124.618 & 2000 & 500 & 39.430 & 45.050 & 2.563 & 24.844 \\
\hline RM75-03A & 908 & 144 & 127.618 & 3000 & 750 & 21.172 & 26.792 & 2.563 & 16.886 \\
\hline RM75-03B & 905 & 142 & 125.618 & 3000 & 750 & 16.876 & 22.496 & 2.563 & 14.726 \\
\hline RM75-03C & 908 & 141 & 124.618 & 3000 & 750 & 21.172 & 26.792 & 2.563 & 16.886 \\
\hline RM75-03D & 911 & 141 & 124.618 & 3000 & 750 & 21.300 & 26.920 & 2.563 & 16.962 \\
\hline
\end{tabular}

Source: The Author

Table 7

Linear regression of datas

\begin{tabular}{ccccccc}
\hline Specimens & $\begin{array}{c}\mathbf{X} \\
(\mathbf{1 / m m})\end{array}$ & $\begin{array}{c}\mathbf{Y} \\
\left(\mathbf{N} / \mathbf{m m}^{\mathbf{2}}\right)\end{array}$ & $\begin{array}{c}\text { Regression } \\
\text { of results }\end{array}$ & $\begin{array}{c}\text { Vus } \\
(\mathbf{k N})\end{array}$ & $\begin{array}{c}\text { Vus/Vut } \\
\text { Deviation } \\
(\%)\end{array}$ \\
\hline RM75-02A & 0.0020 & 0.2041 & & 23.444 & 1.009 & 0.916 \\
RM75-02B & 0.0020 & 0.1965 & & 22.685 & 1.048 & 4.818 \\
RM75-02C & 0.0020 & 0.2030 & $\mathrm{~m}=93.748$ & 23.579 & 1.015 & 1.500 \\
RM75-02D & 0.0020 & 0.2203 & & 23.232 & 0.935 & -6.488 \\
RM75-03A & 0.0013 & 0.1457 & $k=0.0185$ & 16.628 & 0.985 & -1.528 \\
RM75-03B & 0.0013 & 0.1295 & $k$ & 16.313 & 1.108 & 10.775 \\
RM75-03C & 0.0013 & 0.1492 & & 16.237 & 0.962 & -3.843 \\
RM75-03D & 0.0013 & 0.1494 & & 16.291 & 0.960 & -3.955 \\
\hline
\end{tabular}

Source: The Author 


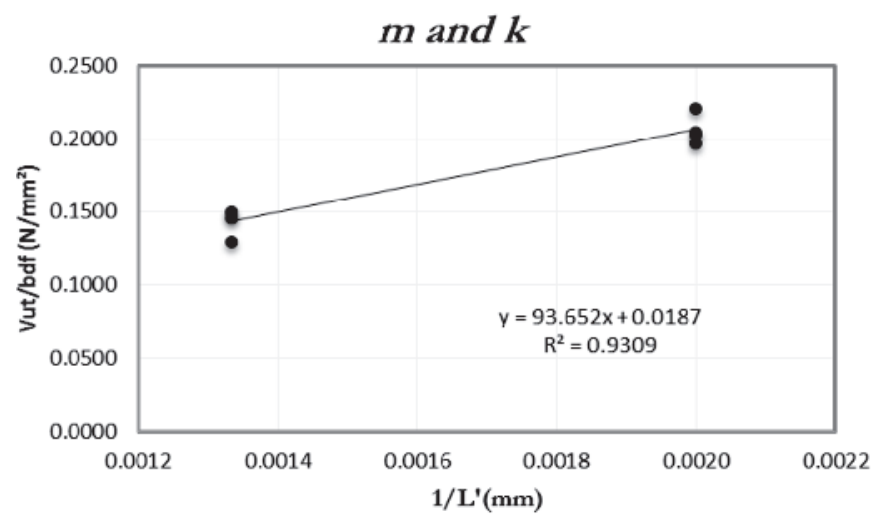

\section{Figure 12}

Linear regression of the test datesfrom normative models

Source: The Author

\subsection{Comparative analysis of the normative and alternative models}

The comparative analysis of the models requires some basic considerations of the main parameters that can influence their behavior during the test, being the collapse load and the geometrical characteristics. The latter is the main factor since directly influences the loading values and behavior of each model. For this reason, it is necessary a careful analysis of the differences presented by the models from the different geometric characteristics. The analysis began by applying the parameters $m$ and $k$ obtained by testing the alternative model in equation 01 , varying its geometric characteristics, so that if approached the geometry of the normative model. And, then it was possible to find the relationship between the longitudinal shear strength of the composite system, Vus, and growing values of shear span and slab width. The results found for this situation were compared with the results found by adopting $m$ and $k$ of the normative model, as can be seen in figures 13 and 14 . Although the parameters $m$ and $k$ obtained during studies on alternative models define the longitudinal shear strength of alternative models, they can't be adopted in the calculation of normative models, since they don't describe their resistance at the interface. By adopting the parameters $m$ and $k$ obtained in the test of the alternative slabs in larger span slabs, regardless of the adopted width, there is a sharp decrease in the theoretical slab strength until the zero value is reached. This value is reached for all specimens in the same shear span which characterizes a limiting span for adoption of this parameter.

\section{Conclusions}

In testing the alternative models, it was concluded that the sizing parameters longitudinal shear, $m$ and $k$, obtained can be reliably used as part of the model sizing process. The deviations found by relating the experimental longitudinal shear resistance capacity (calculated through the presented equations) satisfy the normative requirements, thus allowing to confirm the statement that the found $m$ and $k$ values can be adopted in the procedure of calculation of the alternative model. However, by using the parameters $m$ and $k$, obtained by testing alternative models as a procedure for calculating models in larger dimensional scales, it is possible to realize that there is a decrease in the resistant capacity of these models,
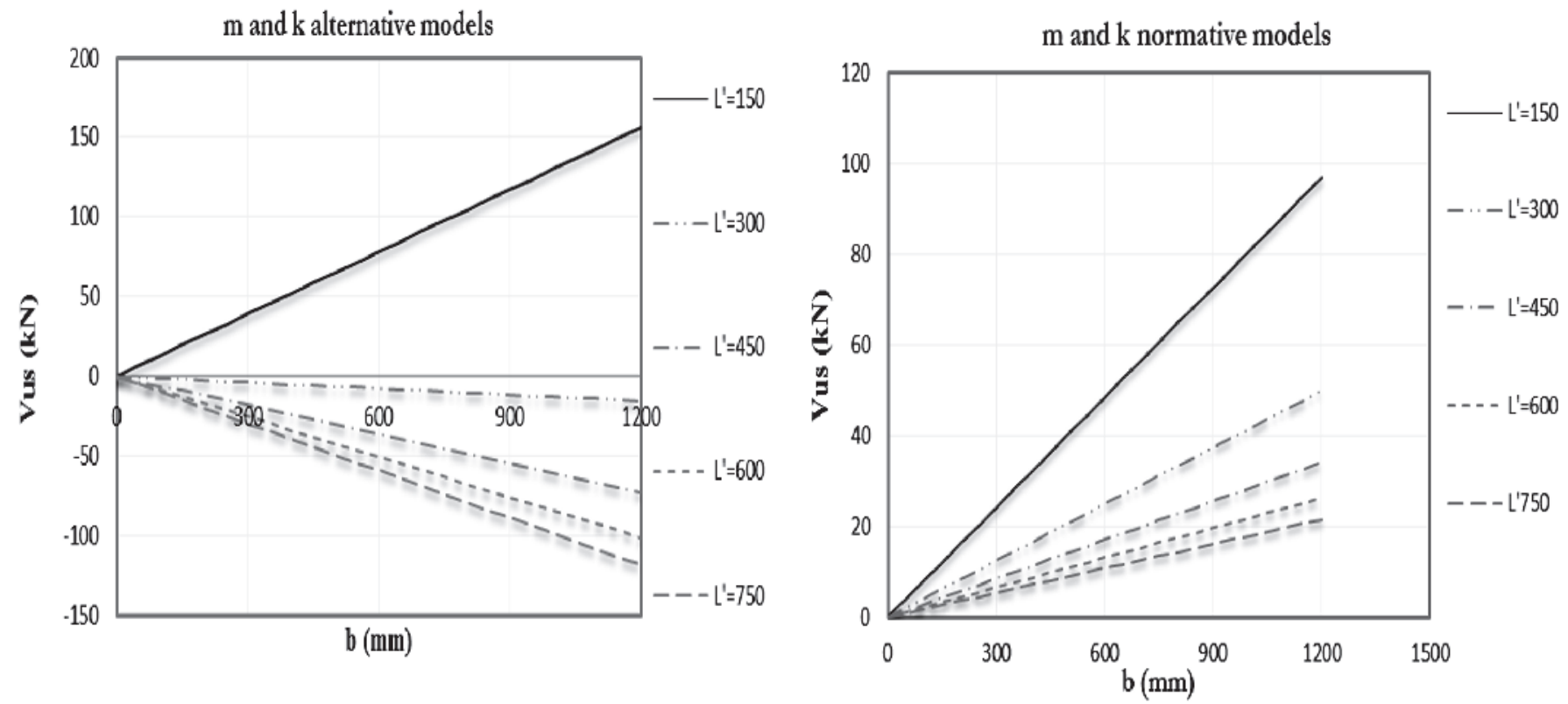

\section{Figure 13}

Longitudinal shear strenght when adopting $\mathrm{m}$ and $\mathrm{k}$ of the alternative and normative models change the width of specimens

Source: The Author 

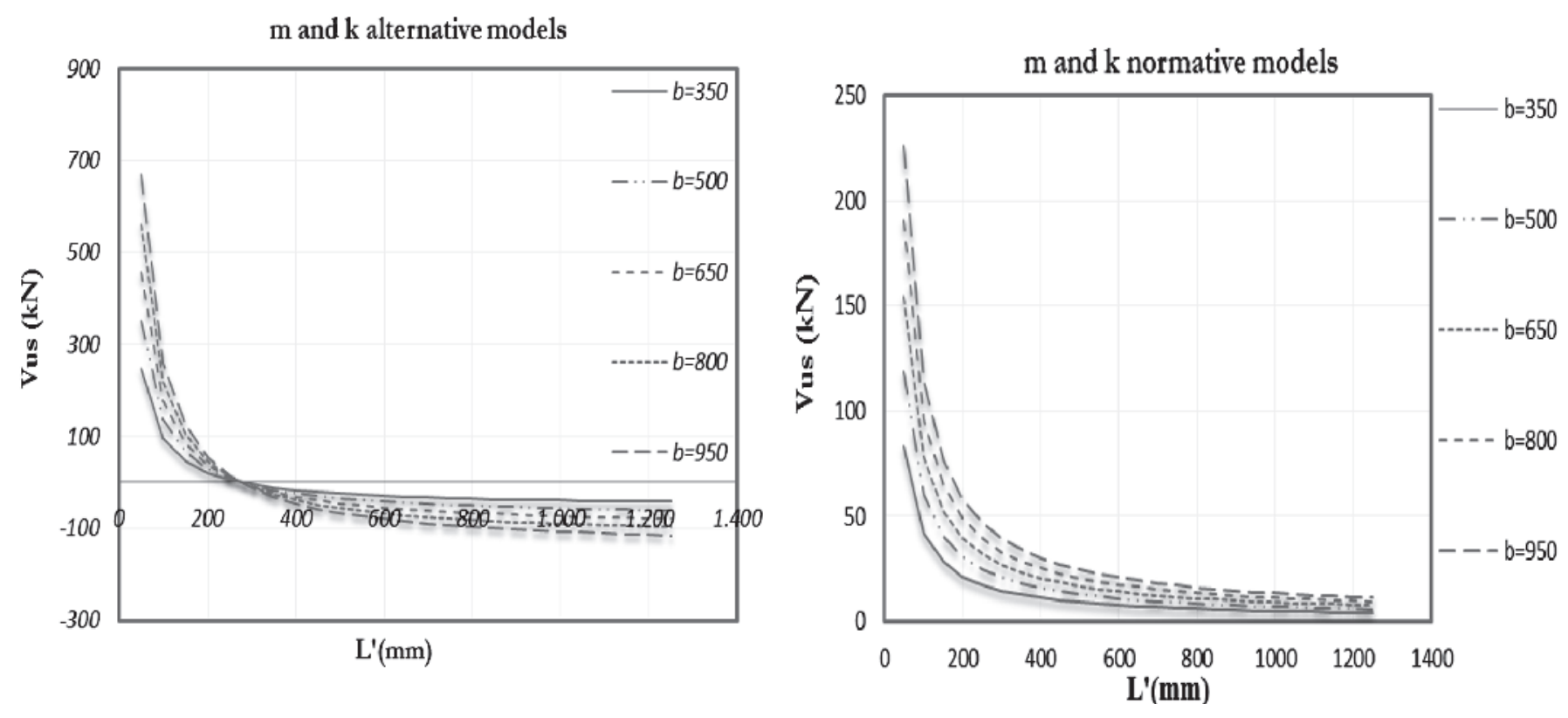

\section{Figure 14}

Longitudinal shear strenght when adopting $\mathrm{m}$ and $\mathrm{k}$ of the alternative and normative models change the shear span of specimens

Source: The Author

regardless of the variable dimension, width or length. It is also noticed the existence of a span limit to which these parameters can be adopted. It is inferred, then, that the $m$ and $k$ parameters found for the alternative models can't be adopted in the procedure of calculation of the normative model, since they present inconsistencies. The analysis of the behavior of the load $x$ deformation graphs of the alternative models allowed that after partial plasticization of the section and approximation of the load that generates relative slippage edge, there is a change in the deformation behavior of the upper flange that spend suffer compression, namely, that the partial interaction between concrete and steel deck after relative slippage generates two neutral lines, one in concrete and one in steel deck, circumstances also confirmed in the bibliographies studied. About the mode of collapse of alternative models, it is noticed a clear influence of the metallic mesh on its resistant capacity, even after the loss of mechanical interaction between steel deck and concrete cover. Moreover, after the appearance of the first cracks it is possible to notice large deformations until collapse, characterizing a ductile behavior.

A clear problem with alternative models is the distance between the applied load and the supports and the height of the models. These factors may cause the load to be transferred almost directly to the supports and not by longitudinal shear. Nevertheless, it is possible to observe in the alternative models the transfer of forces also through shear in the interface zone. Through tests on normative models, it became possible to find values for $m$ and $k$ that reliably represent the interaction between the RM75 steel deck and the concrete cover, since the deviations between the theoretical and experimental relationship didn't exceed $+-15 \%$ according to normative specifications. Nevertheless, the longitudinal shear-resistant capacity was of low intensity, demonstrating that there was a low interaction between steel deck and concrete cover. Is believed that be due to the low efficiency of the steel deck surface dents; It is therefore recommended to ensure a better arrangement of surface dents by adopting deeper and higher amount by linear meter. Or, evaluate the process of mechanical shaping of the steel deck in such a way that possible flaws in this step can be corrected.

The evaluation of the collapse of normative models shows that there was no considerable influence of the mesh on the obtained results. The collapse occurred with significant relative slippage only near the last load, that is, the rupture occurred in a fragile manner. Another unobserved characteristic compared to the alternative model was the occurrence of a process of continuous appearance of cracks before collapse.

Through this work, it is expected to assist research of new procedures to determine the parameters $m$ and $k$.

\section{Appreciation}

The authors thank Pengec Engenharia e Consultoria, in the person of Dr Vinicius Maia Barreto de Oliveira. To the Laboratório de Estruturas S.P. TIMOSHENKO and Centro Tecnológico da Argamassa (CETA), of the UFBA Polytechnic School, for all the assistance available in the production and testing of the models.

\section{Bibliography}

[1] FILHO, O. T. B. Estudo comparativo de respostas estruturais antes da cura do concreto de fôrmas metálicas 
incorporadas às lajes. Belo Horizonte: Dissertação de Mestrado Universidade Federal de Minas Gerais - Belo Horizonte, (2003).

[2] AMERICAN NATIONAL STANDARDS INSTITUTE/ STEEL DECK INSTITUTE ANSI. T-CD-2011 Test standard for composite steel deck- slabs, (2011).

[3] ABDULLAH, R. \& EASTERLING, W. S., (2007). Determination of Composite Slab Strength Using a New Elemental Test Method. Journal of Structural Engineering, Vol. 133, № 9, September1, 2007. ASCE.

[4] CAMPOS, P. C. "Efeito da continuidade no comportamento e na resistência de lajes mistas com fôrma de aço incorporada". Belo Horizonte: Dissertação de Mestrado, Universidade Federal de Minas Gerais- Belo Horizonte, (2001).

[5] COSTA, R. S Análise de um sistema de lajes mistas considerando a influência do atrito dos apoios e a avaliação do momento de inércia efetivo. Belo Horizonte: Dissertação de Mestrado, Universidade Federal de Minas GeraisBelo Horizonte, (2009).

[6] DANIELS, B., \& CRISINEL, M. (1993.a). Composite Slab Behavior and Strength Anlysis. Part I: Calculation Produced. Journal of Structural Engineering, Vol. 119, № 1 , January 1993. ASCE.

[7] JOHNSON, R. P.; ANDERSON, D. Designers'Guide to EN 1994-1-1 Eurocode 4: Design of Composite Steel and Concrete Structures - Part 1.1: General Rules and Rules for Buildings, first edition, Thomas Telford Publishing, London, 2004.

[8] ARAÚJO, G. S. Análise do comportamento e da resistência de um sistema de lajes mistas pelo método da interação parcial. Belo Horizonte: Dissertação de Mestrado Universidade Federal de Minas Gerais- Belo Horizonte, (2008).

[9] SELEIM, S. AND SCHUSTER, R. (1985). "Shear-Bond Resistance of Composite Deck-Slabs," Canadian Journal of Civil Engineering, National Research Council of Canada, Vol. 12, pp. 316-324.

[10] EUROPEAN STANDARD-EUROCODE 4: Design of composite steel and concrete structures-part 1-1: General rules and rules for buildings, (1994).

[11] SCHUSTER, R. M. Strength and behavior of cold-rolled steel-deckreinforced concrete floor slabs. lowa State University of Science and technology Ames, lowa, (1970).

[12] ASSOCIAÇÃO BRASILEIRA DE NORMAS TÉCNICAS. NBR 8800. Projeto de estruturas de aço e de estruturas mistas de aço e concreto de edifícios. Rio de Janeiro, (2008)

[13] BRENDOLAN, G. Análise comparativa da resistência de um sistema de lajes com fôrma de aço incorporada. Belo Horizonte: Dissertação de Mestrado, Universidade Federal de Minas Gerais- Belo Horizonte, (2007).

[14] JOHNSON, R. P. Composite structures of steel and concrete- Volume 1 Beams, Slabs, Columns, and frame for buildings, Second Edition. Blackwell Scientific Publications, (1994).

[15] ASSOCIAÇÃO BRASILEIRA DE NORMAS TÉCNICAS. NBR 6892 (Ensaio de tração à temperatura ambiente),2002.
[16] ASSOCIAÇÃO BRASILEIRA DE NORMAS TÉCNICAS. NBR 5739 (Concreto- Ensaio de compressão de corpos de prova cilíndricos).

[17] ASSOCIAÇÃO BRASILEIRA DE NORMAS TÉCNICAS. NBR 8522 (Concreto- Determinação dos módulos Estáticos de elasticidade e de deformação à compressão). 